\title{
New Insights on the Role of the Mesenchymal-Hematopoietic Stem Cell Axis in Autologous and Allogeneic Hematopoiesis.
}

\author{
Tatiana D. Zorina
}

Thomas Jefferson University, Tatiana.zorina@jefferson.edu

Follow this and additional works at: https://jdc.jefferson.edu/jchpfp

Part of the Medical Biotechnology Commons

Let us know how access to this document benefits you

\section{Recommended Citation \\ Zorina, Tatiana D., "New Insights on the Role of the Mesenchymal-Hematopoietic Stem Cell Axis in Autologous and Allogeneic Hematopoiesis." (2021). College of Health Professions Faculty}

Papers. Paper 2.

https://jdc.jefferson.edu/jchpfp/2

This Article is brought to you for free and open access by the Jefferson Digital Commons. The Jefferson Digital Commons is a service of Thomas Jefferson University's Center for Teaching and Learning (CTL). The Commons is a showcase for Jefferson books and journals, peer-reviewed scholarly publications, unique historical collections from the University archives, and teaching tools. The Jefferson Digital Commons allows researchers and interested readers anywhere in the world to learn about and keep up to date with Jefferson scholarship. This article has been accepted for inclusion in College of Health Professions Faculty Papers by an authorized administrator of the Jefferson Digital Commons. For more information, please contact: JeffersonDigitalCommons@jefferson.edu. 
New Insights on the Role of the Mesenchymal-Hematopoietic Stem Cell Axis in

Autologous and Allogeneic Hematopoiesis

Tatiana Zorina

Thomas Jefferson University, Jefferson College of Health Professions, Department of Medical Laboratory Science and Biotechnology, Philadelphia, PA

Running title: New Insights on Mesenchymal-Hematopoietic Stem Cell Axis

Corresponding author:

Tatiana Zorina, MD, PhD

130 S.9 $9^{\text {th }}$ St.

Edison Bldg., Office 2121

Philadelphia, PA 19107

E-mail: $\quad$ tatiana.zorina@jefferson.edu

Phone : $\quad 215-503-8182$

FAX: $\quad 215-503-2189$ 


\section{Abstract}

Cytoreductive protocols are integral both as conditioning regimens for bone marrow transplantation and as part of therapies for malignancies, but their associated comorbidities represent a long-standing clinical problem. In particular, they cause myeloablation that debilitates the physiological role of mesenchymal stem and precursor cells (MSPCs) in sustaining hematopoiesis. This review addresses the damaging impact of cytoreductive regimens on MSPCs. Additionally, it discusses prospects for alleviating the resulting iatrogenic comorbidities. New insights into the structural and functional dynamics of hematopoietic stem cell (HSC) niches reveal the existence of 'empty' niches and the ability of the donor-derived healthy HSCs to outcompete the defective HSCs in occupying these niches. These findings support the notion that conditioning regimens, conventionally used to ablate the recipient hematopoiesis to create space for engraftment of the donor-derived HSCs, may not be a necessity for allogeneic bone marrow transplantation. Additionally, the capacity of the MSPCs to cross-talk with hematopoietic stem cells, despite MHC disparity, and suppress graft versus host disease indicates the possibility for development of a conditioning-free, MSPCs-enhanced protocol for bone marrow transplantation. The clinical advantage of supplementing cytoreductive protocols with MSPCs to improve autologous hematopoiesis reconstitution and alleviate cytopenia associated with chemo and radiation therapies for cancer is also discussed. 


\section{Key Words}

Hematopoietic stem cell niches

Mesenchymal stem and progenitor cell

Allogeneic hematopoietic chimerism

Myeloablative conditioning

Cytoreductive regimens for treatment of malignancies

Pancytopenia 


\section{Abbreviations}

$\mathrm{BM}$ - bone marrow

BMT - bone marrow transplantation

CAR cells - CXCL12-abundant reticular cells

CFU-F - fibroblast colony-forming unit

EV - extracellular vesicle

GVHD - graft versus host disease

HIV - human immunodeficiency virus

HLA - human leukocyte antigen

HSC - hematopoietic stem cell

LT-HSC - long-term repopulating subset of HSCs

MAC - myeloablation conditioning

MAT - monoclonal antibody therapy

MSC - mesenchymal stem cell

MSPC - mesenchymal stem and progenitor cells

$\mathrm{Nes}^{\text {peri }}-\mathrm{Nestin}^{+}$periarteriolar cells

$\mathrm{Nes}^{\text {retic }}-\mathrm{Nestin}^{+}$reticular cells

NG2 - neural glial antigen

NMC - nonmyeloablative

OPN - osteopontin

RIC - reduced intensity conditioning

SDF1 - stromal cell-derived factor-1

ST-HSC - short-term repopulating subset of HSCs

T1D - type 1 diabetes

Treg - T regulatory (cells) 


\section{Introduction}

Cytoreductive therapies are currently broadly used to treat a variety of malignancies and to induce allogeneic hematopoietic chimerism for treatment of malignant $[1,2]$ and non-malignant [3-5] disorders. When this approach is used for cancers, the primary therapeutic objective is control of proliferation in the malignant growths. When this approach is used for non-malignant diseases, the primary sought-after effect is suppression of immune and autoimmune reactions. Despite the significant therapeutic benefit of cytoreductive therapies for many fatal disorders, they may also result in serious comorbidities affecting the gastro-intestinal tract, reproductive organs, pulmonary, urothelial and cardiovascular systems, and hematopoiesis [6,7]. Bone marrow (BM) aplasia and pancytopenia contribute considerably to the adverse side-effects of cytoreductive protocols.

With the understanding that cytoreductive regimens damage mesenchymal stem and progenitor cells' (MSPCs) ability to sustain autologous hematopoiesis impaired by anti-cancer chemo and radiation therapies and engraftment of the allogeneic hematopoietic stem cells (HSC) under conditioning regimens, a search has begun for a means to protect this very important function of BM stroma. This review provides a synopsis on the current knowledge about different mesenchymal-compartment subsets within HSC niches and discusses the prospect for development of the MSPC-based protocols for: (i) supplementation into myeloablative regimens to support autologous hematopoietic reconstitution and (ii) sustaining allogeneic BM engraftment. The rationale for incorporating MSPCs into cytoreductive regimens is based on new insights on the dynamic structure of BM and the critical role of MSPCs within HSC niches under physiologic, pathologic, and therapy-associated conditions [8].

\section{Hematopoietic stem cell niches \& BM transplantation challenges}


The unitary theory of blood cells origin from HSCs was postulated by Alexander Maximow [9] and later was confirmed experimentally by Till and McCulloch [10]. HSCs represent a small subpopulation of cells within BM originally identified as $\mathrm{CD} 34^{+}$cells capable of hematopoietic reconstitution. The two basic features of HSCs are their ability to self-renew and to differentiate into mature blood cells. These functionally different HSC subsets are supported by long-term (LT-HSCs) and short-term (ST-HSC) repopulating HSC niches [11-13].

Bone marrow transplantation has been explored for the treatment of a vast variety of disorders, however, comorbidities associated with cytoreductive conditioning regimens and the risk of graft versus host disease (GVHD) limit its broad clinical application [14]. BM is the most sensitive tissue to human leukocyte antigen (HLA) disparity. In addition to major histocompatibility complex (MHC) antigens, numerous minor histocompatibility antigens play a role in allogeneic BM engraftment [15]. HSC engraftment implies that these cells have the ability to migrate into the host's BM microenvironment, known as HSC niches, and undergo self-renewal or differentiation into mature blood cells [16-18]. This concept led to the conclusion that the host's HSC niches must be ablated to create a space for donor-derived BM to engraft [18-20].

In conventional BMT protocols, recipient niches are damaged by ablative conditioning regimens resulting in cytopenia [21]. Different conditioning protocols are grouped into total myeloablative (MAC) [22], non-myeloablative (NMC) [23], and reduced-intensity conditioning (RIC) [24]. Additionally, monoclonal antibody therapy (MAT) has also been used to facilitate BM engraftment $[25,26]$. MAT is not conventionally considered as a conditioning regimen; however, it also leads to cytopenia and its associated co-morbidities.

Despite the improvements in clinical outcomes achieved by reducing the conditioning intensity, the complications caused by these regimens often outweigh their therapeutic benefits. An optimal, clinically safe, and effective protocol for BMT remains to be established. Despite the 
associated co-morbidities, myeloablation remains a standard component of the conditioning regimen required for BMT. This review presents evidence to challenge its necessity, especially as part of treatment for non-malignant disorders.

\section{The mesenchymal cell compartment of HSC niches during hematopoietic homeostasis}

HSC niches are complex, functionally dynamic structures sustaining either HSC self-renewal or their differentiation into mature blood cells. These two functionally discrete types of niches populated predominantly by HSCs in the dormant and proliferative status respectively have distinct spatial allocations within BM. HSCs migrate between these niches or exit into peripheral circulation $[27,28]$. They can also switch from dormancy to proliferation during homeostasis and under different stimuli [29]. Ultimately, HSCs' fate (quiescence vs proliferation, self-renewal vs differentiation, migration and engraftment) is regulated by their microenvironmental niches [3032]. Mesenchymal stem cells (MSCs), originally identified by Friedenstein, represent one of the major cellular compartments within HSC niches [33].

Research on MSC differentiation into different tissues produced a new branch of reparative medicine. Another essential property of MSCs is their immunomodulatory function [34-36]. The focus of this review is on yet another important role of MSCs, which is in regulating hematopoiesis. The two major types of HSCs niches are endosteal (also known as long term (LT) or periarteriolar due to their proximity to arterioles) and perivascular (also known as short term (ST) or perisinusoidal) niches, which are located around sinusoids in the inner core of BM [37]. The minority of HSCs are in a quiescent state and reside in endosteal niches, while the majority of HSCs, which represent a mixture of dividing and dormant cell populations, are located in perivascular niches [38,39]. 
Cytopenia results from impaired hematopoiesis, and cytoreductive therapy is one of its causative factors. Understanding the role of damaged mesenchymal cells within HSC niches in pathogenesis of this complication is needed to improve the outcomes of anti-cancer treatments and BMT-based therapies. HSCs have a vast regenerative potential. For example, replenishment of $\mathrm{CD} 4{ }^{+}$cells, destroyed by human immunodeficiency virus (HIV), is sustained for years. On the contrary, only a few weeks of cytoreductive therapy results in cytopenia [21]. The potential key mechanisms based on compromised function of the mesenchymal stroma cells compartment in the BM, which are responsible for an abrupt impairment of hematopoietic homeostasis under cytoreductive regimens are discussed in this review.

Regulation of the HSC-MSC axis is mediated through either direct cell-to-cell interactions [31] or by secreted molecules $[37,38]$. The subsets of mesenchymal cells in HSC niches play different roles in hematopoiesis by regulating self-renewal and lineage-specific differentiation of HSCs in homeostasis, pathology, and post-conditioning reconstitution by mediating both of these mechanisms $[39,40]$. A brief review of the current understanding of mesenchymal cell subsets and their structural components sustaining LT- and ST-HSC niches is provided below and illustrated in Figure 1 A, B \& D).

Endosteal HSC niches harbor mesenchymal cells, which are responsible for sustaining LTHSCs. This includes MSPCs and mature osteoblasts $[41,42]$. Osteoblasts sustain LT-HSCs subsets' self-renewal ability $[38,43]$, providing "quiescence" signaling to HSCs via direct interaction [44] or by secreting osteopontin [45]. Depending on their stage of differentiation, MSCs promote either myeloid or lymphoid differentiation $[46,47]$. Osteoclasts are also involved in the regulation of HSC niches and have close interactions with osteoblasts [48]. Nestin and Leptin markers define MSC subsets in both LT- and ST-HSC niches. Nestin ${ }^{+}$cells have BM fibroblast colony-forming unit (CFU-F) activity, the ability to direct MSCs into lineage specific differentiation, and a strong self-renewal potential. Two subtypes of $\mathrm{Nestin}^{+}$cells have been 
identified in mouse BM: Nestin ${ }^{\text {peri }}$ cells adjacent to arterioles and Nestin ${ }^{\text {retic }}$ cells (reticular in shape) associated with sinusoids [39].

Perivascular HSC niches are located in proximity to BM sinusoids and contain a mixture of cells in dormant and proliferative states. The majority of cells in the proliferative state represent a population of lineage-committed progenitors with short-term repopulating potential; these cells are incapable of hematopoietic reconstitution in vivo [49]. CXCL12-abundant reticular (CAR) cells in perivascular niches have a high expression of CXCL12 [50-52]. LepR is another defining marker of stromal cells supporting ST-HSC niches; this population contributes to bone regeneration after irradiation or fracture [40].

The major molecules regulating the MSC-HSC interactions are NG2, Sca-1, SCF/c-Kit, and CXCL12/CXCR4. They have different levels of expression in endosteal and perivascular niches. $\mathrm{NG}^{+} / \mathrm{Nestin}^{\mathrm{Hi}}$ mesenchymal cells in periarteriolar niches promote HSC quiescence, and depletion of $\mathrm{NG}_{2}{ }^{+}$cells reduces the long-term repopulating potential of HSCs in BM [53]. Sca-1, expressed on mesenchymal cells, plays a role in HSC self-renewal and cell lineage differentiation [17,54]. Nestin ${ }^{\mathrm{Hi}}$ periarteriolar mesenchymal cells are Sca- ${ }^{\mathrm{Hi}}[39,55]$, while LepR ${ }^{+}$ CAR cell lack Sca-1 expression [56]. The SCF/c-Kit axis plays an essential role in HSC selfrenewal $[57,58]$. Mutations or conditional deletion of the SCF or c-Kit locus result in hematopoietic aplasia and anemia [59]. LepR ${ }^{+}$CAR cells show a high expression of SCF $[58,60]$. The CXCL12-CXCR4 axis is important for the homing of HSCs within BM [61]. CXCL12 plays a role in regulating both the quiescent and proliferative states of HSCs in strong correlation with the level of this molecule's expression. CXCL12 is about 10-times higher in CAR cells in perivascular HSC niches compared to osteoblasts in endosteal niches [60].

In summary, endosteal and perivascular HSC niches represent distinct sites preferentially harboring either LT- or ST-HSC niches. This is not a status quo condition: rather, HSCs can 
change their phenotype, niche type location, and proliferative versus dormancy status. This flexibility contributes to HSC regulation and to maintaining the cellular subsets balance in response to physiologic, pathologic, and therapeutic stimuli [38](38). The mesenchymal stem cells in HSC niches, supporting either LT- or ST-HSC populations, have characteristic phenotypes (Table 1).

\section{Impact of myeloablation on function of the MSC/HSC axis}

The chemo and radiation therapies for treating malignancies, the conditioning protocols for BMT, as well as the immunosuppressive therapies for autoimmune conditions and organ transplantation represent different modalities of cytoreductive regimens. The adverse effects of these regimens are often severe and multifactorial, affecting numerous organs. One of them is the deteriorating effect on hematopoiesis with resulting anemia, thrombocytopenia, and pancytopenia. Hematopoietic homeostasis is sustained through the balance between symmetric and asymmetric division of HSCs. Symmetrical division sustains self-renewal of HSCs. These cells primarily remain in the $\mathrm{G}_{0}$ cell cycle-phase under homeostatic condition [62]. Asymmetric division produces one cell with its original properties and another with the potential for lineage specific differentiation $[12,63,64]$. Numerous factors regulating these processes are altered by cytoreductive regimens which affect the physiological balance between ST- and LT-HSCs niches [65-67]. Stromal cells in the HSC niches regulate quiescent, nonproliferative state of the HSCs, which protect them from both direct ionizing radiation-induced killing and indirect cytokine and free radical mediated killing [68]. A study employing genetic barcode-based technology demonstrated homogenous differentiation of all engrafted HSC populations in unconditioned mice. By contrast, in mice subjected to conditioning regimes, only a small subset of HSC clones were involved in differentiation [65].

Mesenchymal cell subsets regulating hematopoiesis are damaged by cytoreductive regimens by numerous mechanisms inducing defects at the cellular, protein and molecular levels. 
Osteoblasts are reported to respond to radiation by inducing HSC migration toward endosteal regions and eliciting "quiescence" signaling [69]. Anomalies in the CXCL12-CXCR4 axis were demonstrated to contribute to the pathogenesis of pancytopenia in response to myeloablation [51].

Exposure to ionizing radiation (IR) induces long-term persistent senescence status in different cell lines that contributes to reduced functionality of the affected tissues [70]. This was shown to be the case for stromal BM cells as well. It was demonstrated in the mouse model that exposure to the IR triggers expression of the senescence markers and increases expression of $p 16$ (INK4a)/p19(ARF), and that the IR-induced damage to the BM microenvironment can produce an adverse effect on hematopoiesis in an Ink4a/arf-dependent manner [71]. The studies evaluating the effects of radiation on human bone marrow mesenchymal stromal cells also demonstrated induction of the senescence status in these cells when exposed to a low dose of IR [72]. A study by Cameron et al. identified Nrf2 as an important factor in the radiation response of normal tissues. They showed that Nrf2-mediated gene expression is an important regulator of a hematopoietic cell compartment response to radiation, where Nrf2 promotes the survival of irradiated osteoblasts that support long-term hematopoietic stem cell (LT-HSC) niches. Loss of Nrf2 in LT-HSCs increases stem cell intrinsic radiosensitivity. An Nrf2 deficiency drives LT-HSCs from a quiescent to a proliferative state, which results in hematopoietic exhaustion and reduced engraftment after myoablative irradiation [73].

Exposure to high levels of radiation is known to cause an acute radiation syndrome causing BM failure and resulting anemia, thrombocytopenia, and pancytopenia leading to life-threatening infections. The role of damaged MSCs in such conditions is supported by data providing the evidence that co-culture of human macrophages with human mesenchymal stem cells or with exosomes isolated from MSCs can significantly enhance survival of mice exposed to lethal 
irradiation [74]. These and other data support the need to further explore the potential of using the MSCs to treat radiation-induced damage to different tissues [75].

A major target of low dose radiation effects are the stem cells. These cells can accumulate radiation effect during their relatively long life-span, ultimately affecting their function. However, the common perception about MSCs is that they are relatively radioresistant. This concept can be challenged based on the data demonstrating that the radiation sensitivity of mammalian cells does not always follow a simple linear dose/effect response, with numerous cell types showing hyper-radiosensitivity to very low levels of radiation with no correlation with the cell survival response to the high doses [76,77]. Another interesting observation revealed that in the MSC cells, the number of $\mathrm{Ki} 67^{+}$cycling cells did not reduce with an increase of the radiation dose. Also unexpected was the observed lack of direct correlation between dose of radiation and number of the apoptotic cells. It was shown in the proliferative and functional acid-betagalactosidase assays that a large percentage of the MSCs entered senescence and exhibited radiosensitivity in response to very low dose of radiation (40 mGy) while exhibiting radioresistance in response to higher doses of radiation (up to 2000 mGy) [72].

Unlike discrepancies regarding the role of the mesenchymal components in the HSC niches in compromised hematopoiesis, the fact that radiation exposure impairs hematopoiesis is undeniable. New therapeutic modalities are being developed to protect, reverse, or, preferably, prevent BM damage associated with exposure to radiation [78]. Conventionally, the BM susceptibility to radiation-induced damage was attributed to high proliferative activity of the hematopoietic stem and precursor cells, as cells with high cell division rates are known to be more radiosensitive [79]. Numerous mechanisms reportedly contribute to the HSC damage in response to radiation, such as TP53 mediated apoptosis, telomere dysfunction affecting lineage differentiation, and induction of senescence [80-82]. Mesenchymal stromal cells, which play a paramount role in sustaining hematopoiesis in the HSC niches in physiologic condition, are 
reported in some studies to be less radiosensitive compared to $[83,84]$. Thus MSCs have been suggested as viable candidates for cell-based therapy of cytoreductive regimen-induced BM aplasia $[85,86]$. It was shown that MSCs can support hematopoiesis in patients with acute radiation syndrome as MSCs promote proliferation of irradiated CD34+ $\mathrm{HSCs}$, rescue these cells from radiation-induced apoptosis, and support hematopoietic reconstitution after co-culture [87]. Other studies have demonstrated that radioprotection can be delivered via MSCs-induced increased secretion of the hematopoietic growth factor Flt3L [88]. Pre-clinical and clinical trials show the effectiveness of the MSCs in sustaining the HSCs engraftment in BMT patients $[89,90]$. The mechanisms of action are suggested to be the secretion of cytokines and growth factors that stimulate hematopoiesis, combined with inhibition of $T$ and dendritic cells-based responses $[91,92]$.

The studies exploring the potential therapeutic applications of the donor-derived MSCs are evolving from the utilization of direct MSC-based therapeutic protocols to the utilization of MSCeducated macrophages and MSC-exosome educated macrophages as adoptive cell therapies for radiation induced malfunction of mesenchymal stromal cells in the HSC niches in the BM [93].

Chemotherapy is another iatrogenic tool, which, like radiation, has a cytoreductive effect with potential to cause BM aplasia and associated comorbidities. Hematopoietic recovery after chemotherapy can be one of the most challenging aspects of cancer patient management. One of the potential pathogenic mechanisms of flawed hematopoiesis under this therapy is chemotherapy-induced damage of the stromal components of the BM. It was shown over twenty years ago by estimation of the frequency of the colony forming units-fibroblasts (CFU-f) in the $\mathrm{BM}$ of the recipients of BMT that the BM stromal microenvironment is seriously and irreversibly damaged after BMT (based on 12-year-long follow up) [94]. 
Kemp et al. compared the phenotype and functional properties of BM-derived MSCs from untreated patients with hematological malignancy and those treated with high-dose chemotherapy (HDC). This study demonstrated a significant reduction in MSC expansion and MSC CD44 expression by MSCs derived from patients receiving HDC regimens, thus implicating disadvantage in the use of the autologous MSCs in chemotherapeutically-treated patients [95]. Another study by this group demonstrated that the exposure of MSCs to the chemotherapeutic agents cyclophosphamide and melphalan has strong negative effect on MSC expansion and CD44 expression. In addition, the functional injury of the MSCs was reflected by their decreased ability to support hematopoietic cell migration and repopulation [96]. The commonly used chemotherapy drugs cytarabine and daunorubicin were tested for their effect on BM-residing MSCs and drug-induced alteration of hematopoiesis-supportive function of these cells. The chemotherapeutic drugs induced altered ability of the MSCs to support hematopoietic reconstitution was attributed to increased intracellular level of reactive oxygen species and induction of cell apoptosis [97]. Somaiah et al. evaluated the effect of the chemotherapeutic drugs cytarabine, daunorubicin, and vincristine on differentiation, phenotypic and gene expression changes in MSCs, and tested the anti-cancer effects of drug-treated MSC on leukemia cells. The findings in this study demonstrated that the assayed drugs altered the phenotype and the osteogenic and adipogenic differentiation of MSCs and rendered leukemic cells in these patients more chemo resistant [98].

Thus, the majority of studies are in agreement that the chemotherapeutic drugs have negative effects on MSCs various functions. However, the recent in vitro study by Lopez et al. demonstrated that human BM-derived MSCs are relatively resistant to treatment with the widely used antimetabolite drugs 5-FU and gemcitabine. In this study the expression of the MSCs surface markers and their multi-lineage differentiation potential was shown to be irrespective of 5-FU or gemcitabine treatment. The high expression levels of enzymes involved in DNA 
metabolism and multidrug resistance transporters in the MSCs addressing contributing factors for the observed readouts. However, the authors did not address in this study the ability of the MSCs to support hematopoiesis [99].

An additional confirmation for the observation that MSCs in the senescent state have decreased ability to support hematopoiesis came from a study by Yuan et al. This study showed that HIV protein p55-gag could induce senescence of MSCs, resulting in their reduced capacity to support expansion of hematopoietic stem cells in vitro [100].

Another correlation between senescent state in the MSCs and their impaired ability to sustain hematopoiesis was demonstrated in patients with myelodysplastic syndromes (MDS). MDSderived MSCs were found to have significantly reduced osteogenic differentiation and altered expression of key molecules involved in the interaction with HSCs, such as Osteopontin, Jagged1, Kit-ligand, and Angiopoietin, and several chemokines. In addition, the MDS-derived MSCs had significantly diminished ability to support CD34+ HSCs in long-term culture [101]. In line with this finding, deficient hematopoiesis was detected in myeloma BM-derived MSCs, which also was shown in association with their senescent state. Specifically, it was shown that myeloma BM mesenchymal stromal cells have an increased expression of senescenceassociated $\beta$-galactosidase, increased cell size, reduced proliferation capacity, and characteristic expression of senescence-associated secretory profile members [102].

BM aplasia associated with cytoreductive regimens-induced senescence status in the mesenchymal stromal cells is illustrated on Figure 1 C \& D.

\section{Challenging the niche-creation dogma for allogeneic HSC engraftment: is myeloablation required for allogeneic HSC engraftment?}

A long-held perception is that ablation of autologous hematopoiesis is required for a successful allogeneic BMT $[32,65]$. To minimize the adverse effects, conditioning regimens have shifted 
from myeloablative conditioning (MAC) to non-myeloablative conditioning (NMC) and reduced intensity conditioning (RIC). While outcomes have improved, the complications remain significant $[65,66]$. BMT conditioning protocols damage HSC niches including their mesenchymal cell components resulting in different levels of pancytopenia [103,104].

A question arises as to whether BM aplasia and pancytopenia resulting from cytoreductive therapy are due to the impaired function of MSPCs sustaining hematopoiesis. Could damage to MSPCs be the key factor responsible for both (i) impaired autologous hematopoietic reconstitution in case of chemo and radiation therapies for malignances and (ii) hindered engraftment of donor HSCs in case of BMT? Does myeloablation damage the niche-stromal components and impair their ability to support hematopoiesis rather than clearing the HSC niche space for donor BM engraftment? We would like to address these queries by discussing two intertwined questions: what is the current view on cellular and molecular level impacts of myeloablation on hematopoiesis, and what are the ablation requirements for HSC engraftment? In addition, a question about the role of MSPCs in the prevention of GVHD is discussed.

Conditioning, as a requirement for BMT, was reexamined after evidence emerged of its damaging effect on the mesenchymal compartment, which has the vital function for supporting hematopoiesis in HSC niches [65,105]. Numerous studies demonstrated the possibility of induction of hematopoietic chimerism without host myeloablation [106-109] and the possibility that dietary valine restriction may reduce iatrogenic complications in HSC transplantation [110]. It was shown that HSC niches are dynamic, rather than invariable, structures $[28,111]$. Healthy donor-derived HSCs have the ability to out-compete diseased host HSCs for niche space during engraftment [107,112]. In addition, empty HSC niches appear to be available for engraftment of donor-derived HSCs [113]. 
Administration of massive doses of BM cells was shown to secure hematopoietic engraftment without conditioning $[106,111,114]$. The stem/precursor cell ratio and genetic composition of transplanted BM were also shown to be significant factors in promoting allogeneic engraftment. A competitive repopulation assays demonstrated that low numbers of HSCs successfully compete with the greater numbers of co-transplanted short-term precursor cells [115]. Additionally, wild-type (healthy) donor HSCs can replace genetically defective HSCs in the recipients BM [112]. Unconditioned BMT transplantation was shown to minimally perturb natural hematopoiesis [65]. Taken together, these data support the rational for further exploration of protocols for allogeneic HSCs transplantation without conditioning.

\section{Potential advantage in adaptation of the MSPCs into therapeutic protocols}

MSPC-based protocols to support autologous hematopoiesis under cytoreductive therapy. Is it possible to avoid pancytopenia associated with cytoreductive regimens for treatment of malignancies? MSCs play a key role in LT- and ST-HSC niche integrity $[46,53,116,117]$. Radiation exposure, chemotherapeutic protocols and other cytoreductive regimens can induce the senescent state and thus play a significant role in impaired ability of MSCs to sustain HSC niche integrity and resulting pancytopenia $[71,118]$. Incorporating MSPCs into protocols of the cytoreductive regimens may, therefore, be a key factor for treatment and prevention of cytopenia. Further research is needed to determine which subset of the mesenchymal cells or their combination would be optimal for such therapies.

MSPC-based protocol to sustain allogeneic HSC engraftment in a conditioning-free BMT. Mesenchymal cells represent a strong candidate for sustaining a conditioning-free allogeneic HSC engraftment without GVHD. As a major cellular component of HSC niches, MSPCs sustain hematopoiesis under homeostatic conditions; when they are damaged by conditioning regimens, their ability to sustain engraftment of allogeneic HSCs is impaired. The ability of MSPCs to cross-talk with HSCs despite allogeneic disparity [119-121] allows these donor- 
derived MSPCs to resume the impaired hematopoiesis-supporting function of the stromal component in the HSC niches and additionally enables the use of the high doses of MSPCs from unrelated donors or commercial sources [122].

Amelioration \& prevention of GVHD. Despite the accumulating evidence supporting the prospect of a clinically successful BMT protocol without conditioning $[108,150]$, its clinical adaptation is hindered by the potential complication of GVHD $[151,152]$. Transplantation of purified HSCs was attempted as a venue to avoid GVHD. However, it significantly reduced HSC engraftment and induction of allogeneic chimerism [153]. To improve engraftment of allogeneic HSCs, while avoiding GVHD, a large cohort of hematopoietic [154,155] and non-hematopoietic cells were studied [52,56,156-158], including osteoblasts, CAR cells, and MSPC populations. However, an adverse-effect-free protocol for induction of allogeneic hematopoietic chimerism remains to be developed.

The concept that MSCs can talk with HSCs across the MHC disparity was first shown by A. J. Friedenstein over 50 years ago when he identified mesenchymal stem cells in the bone marrow [33]. In 1982, T.M. Dexter foreseeably asked: "Is it possible that successful transplantation requires transfusion not only of haematopoietic stem cells but also transfusion and engraftment of stromal cell precursors? We will no doubt know the answer in the near future" [123].

Since then, the insight on phenotype and functions of the MSCs has advanced significantly. It was confirmed that MSCs can be used irrespectively of human leukocyte antigen (HLA) compatibility, as they do not trigger the immunologic reactions. For a while, the absence of the antigenicity of the MSCs was explained by the limited HLA class I expression and lack of expression of the HLA class II and co-stimulatory molecules CD40, CD40 ligand, CD80 and CD86 [124-126]. It was suggested that, in the absence of co-stimulatory molecules, the secondary signal would not be activated, leading to induction of the T cell anergy [127-129]. It 
was demonstrated that MSCs do not elicit proliferative responses from allogeneic T cells in culture [130] and that allogeneic MSCs transplantation is feasible and safe in various animal models [131-135] and in humans [125,136].

Numerous clinical trials [140,142-144] and veterinary practice studies [131,135,145] exploring the therapeutic adaptation of the MSCs in a variety of malignant $[137,138]$ and non-malignant [125,139-141] disorders prompted further studies aiming at elucidating the mechanisms underlying their toleranogenic properties. Klyushnenkova et al. showed that immunotoleranogenic properties of the MSCs are not due to the lack of the co-stimulatory molecules expression, but to their ability to suppress T cell proliferation [9]. Treatment of MSCs in this study with INF, or transduction with B7-1 or B7-2, did not enhance the ability of these cells to stimulate alloreactive T cell proliferation. The ability of the T cells, removed from the culture with MSCs, to proliferate in response to stimulation with allogeneic peripheral blood mononuclear cells supported the conclusion that MSCs have immunosuppressive property irrelevant to the lack of the co-stimulatory molecules expression. Suppression of alloreactivity by MSCs has been reported in humans [127] as well as in baboon [146] and mouse models [147].

In addition, it was demonstrated that MSCs can be immunoprivileged as well as immunosuppressive. They are incapable of inducing allogeneic lymphocytes proliferation in mixed lymphocyte culture, have inhibitory effect on lymphocyte proliferation, and secrete antiinflammatory cytokines IL-10 and TGF- $\beta$ [148].

The further studies of the immunomodulatory mechanisms of the MSCs revealed that these cells have potent immunoregulatory abilities by interacting with cells of the adaptive and innate immune system. They inhibit the differentiation of T cells into T helper 17 (Th17) cells and repress their proliferation, while promoting generation of T regulatory (Treg) cells. The bidirectional immunoregulatory dialogue between MSCs and Th17 cells is mediated by soluble 
factors, extracellular vesicles, mRNAs, miRNAs, cell-to-cell contact, and the transfer of organelles [149].

Incorporation of MSPCs into BMT protocol presents additional significant clinical advantage due to their capacity to suppress GVHD [159-161]. GVHD is a potentially life-threatening complication of allogeneic BMT, and is one of the major factors limiting the broad application of this therapeutic modality for hematological malignancies [162] and non-malignant disorders [163-165]. GVHD is classified into acute and chronic GVHD (aGVHD and cGVHD, respectively). [166].

Adaptation of the MSCs has been reported to be an effective therapeutic tool for the treatment, amelioration, and even prevention of GVHD. The mechanisms of the immunomodulatory effects of the MSCs mediating these clinically beneficial outcomes are under intensive research [144,167-169]. It was shown that amelioration of the inflammatory reactions in GVHD by MSCs is associated with increased Treg cell populations and decreased secretion of the proinflammatory cytokines. The suggested mediators of these outcomes are MSC-secreted TSG6, IL-10, PGE2, vascular endothelial growth factor, and TGF $\beta 1$ [170].

Further modifications of the MSC-based protocols for amelioration of GVHD revealed the potential for substitution of the cellular inoculum of the MSCs by BM-MSC-derived extracellular vesicles (EVs), administration of which recapitulated the therapeutic effects of the cell-based protocols. Systemic infusion of human BM-MSC derived EVs was shown to prolong the survival of mice with aGVHD in association with reduced multiorgan damage, preservation of Treg cell population, and suppression of the naïve T cells differentiation from naïve to effector cells phenotype [171]. It was also shown that MSCs have ability to enhance haematopoietic engraftment and hematological recovery after both autologous [172] and allogenic [137,173] BMT. This property may become crucial in the cytoreductive regimens, specifically not only in 
improving the allogeneic BM engraftment, but also in supporting autologous hematopoiesis reconstitution after its damage by chemo and radiation therapies for cancers. Koc et al. were the first to report improvement of haematopoietic engraftment when autologous BM-MSCs were cotransplanted with HSCs [172]. These findings were confirmed by results from the recent preclinical studies where MSCs were able to delay the onset of GVHD $[174,175]$.

Newly revealed additional mechanisms contributing to the preventive effect of MSCs on GVHD provide an explanation for an existing paradox of the observed immunomodulatory effect following the MSC infusion in association with failure of their long-term engraftment. The proposed explanation is that MSC immunomodulation depends on interaction with cytotoxic NK and T cells of the recipient. The apoptosis of the transplanted MSCs triggered by these immune cells is, according to this study, a requirement for the immunosuppressive outcome of MSCs transplantation. Additional confirmation for this theory is the finding that the cytotoxicity of the host's cells and resulting apoptosis of the transfuse MSCs directly correlate with the immunomodulatory effect of these cells [174].

In disagreement with the numerous reports regarding the effectiveness of MSCs in ameliorating GVHD, a recently published analysis of over two dozens large randomized controlled trials with enrollment of patients with hematologic malignancies concluded that MSC-based therapy to ameliorate aGVHD was not effective [176]. Indeed, outcomes are variable in different institutions and among the patients subjected to MSC-based protocols for therapy of GVHD. To eliminate these discrepancies and improve consistency in therapeutic outcomes, new clinical protocols need to be developed that define the optimal origin of the MSCs, the dose for their administration, and the cellular composition based on research that elucidates the mechanisms underlying their GVHD suppressive effects [177].

\section{Summary and conclusions}


Mesenchymal stem and precursor cells have wide therapeutic potential. This review discussed their role in sustaining autologous and allogeneic hematopoiesis in physiologic condition and under cytoreductive therapies. MSPCs have been shown to play a critical role in hematopoietic homeostasis. Cytoreductive therapies appear to damage their ability to sustain hematopoiesis and contribute to BM aplasia and the onset of cytopenia $[53,62,104,160]$. These data suggest that incorporating MSPCs into chemo, radiation, and immunosuppressive therapies could sustain autologous hematopoietic reconstitution and alleviate cytopenia, comorbidity almost unavoidable in association with these therapeutic regimens.

MSPCs also hold therapeutic potential for improving outcomes of allogeneic hematopoietic chimerism. HSC niches are dynamic structures. Empty niches that self and donor-derived HSCs can occupy are available within BM [114]. Healthy hematopoietic donor cells can out-compete the diseased recipient's HSCs to occupy recipient HSC niches [107,113]. These findings support the notion that the need for 'clearing space' for BM engraftment is a misconceived paradigm and that conditioning can be eliminated from BMT procedure. The ability of mesenchymal cells to: (i) sustain allogeneic hematopoiesis across MHC disparity and (ii) prevent GVHD make them a strong candidate for the development of a MSPCs-supplemented, conditioning-free BMT protocol [6].

The mesenchymal cell subsets, based on their phenotype, stage of maturation and source of origin (e.g., BM, umbilical cord, adipose tissue) as well as the cell dosage and MSPC/HSC ratio for supplementation into cytoreductive regimens have yet to be identified. Further exploration of the MSPCs potential to compensate the function of mesenchymal stroma damaged by cytoreductive regimens could lead to new MSPCs-supplemented therapeutic regimens for malignancies. Development of the MSPCs-based conditioning-free protocol for BMT could open a new venue for treatment of non-malignant disorders. 


\section{Author Disclosure Statement}

No competing financial interests exist.

\section{Acknowledgements}

Author would like to thank Dr. Paul Hunter for help with bibliography and Jennifer Wilson and

Dmitri Zorine with preparation of the manuscript.

\section{REFERENCES}

1. Galaverna F, A Ruggeri and F Locatelli. (2018). Myelodysplastic syndromes in children. Curr Opin Oncol 30: 402-408.

2. Bensinger WI, CD Buckner, K Shannon-Dorcy, S Rowley, FR Appelbaum, M Benyunes, R Clift, P Martin, T Demirer, R Storb, M Lee and G Schiller. (1996). Transplantation of allogeneic CD34+ peripheral blood stem cells in patients with advanced hematologic malignancy. Blood 88: 4132-4138.

3. Locatelli F and D Pagliara. (2012). Allogeneic hematopoietic stem cell transplantation in children with sickle cell disease. Pediatr Blood Cancer 59: 372-376.

4. Wu Y, L Chen, PG Scott and EE Tredget. (2007). Mesenchymal stem cells enhance wound healing through differentiation and angiogenesis. Stem Cells 25: 2648-2659.

5. Yolcu ES, H Shirwan and N Askenasy. (2017). Mechanisms of Tolerance Induction by Hematopoietic Chimerism: The Immune Perspective. Stem Cells Transl Med 6: 700-712.

6. Blaise D, R Devillier, AG Lecoroller-Sorriano, JM Boher, A Boyer-Chammard, R Tabrizi, P Chevallier, $N$ Fegueux, A Sirvent, M Michallet, JO Bay, S Furst, J El-Cheikh, L Vincent, T Guillaume, C Regny, N Milpied, L Castagna and M Mohty. (2015). Low non-relapse mortality and long-term preserved quality of life in older patients undergoing matched related donor allogeneic stem cell transplantation: a prospective multicenter phase II trial. Haematologica 100: 269-274.

7. Mohty M, F Malard and BN Savani. (2015). High-dose total body irradiation and myeloablative conditioning before allogeneic hematopoietic cell transplantation: time to rethink?. Biol Blood Marrow Transplant 21: 620-624.

8. Black L and T Zorina. (2020). Cell-based immunomodulatory therapy approaches for type 1 diabetes mellitus. Drug Discov Today 25: 380-391.

9. Konstantinov IE. (2000). In search of Alexander A. Maximow: the man behind the unitarian theory of hematopoiesis. Perspect Biol Med 43: 269-276. 
10. TILL JE and EA MCCULLOCH. (1961). A direct measurement of the radiation sensitivity of normal mouse bone marrow cells. Radiat Res 14: 213-222.

11. Krause DS, T Ito, MJ Fackler, OM Smith, MI Collector, SJ Sharkis and WS May. (1994).

Characterization of murine CD34, a marker for hematopoietic progenitor and stem cells. Blood 84: 691701.

12. Sun J, A Ramos, B Chapman, JB Johnnidis, L Le, YJ Ho, A Klein, O Hofmann and FD Camargo. (2014). Clonal dynamics of native haematopoiesis. Nature 514: 322-327.

13. Busch K, K Klapproth, M Barile, M Flossdorf, T Holland-Letz, SM Schlenner, M Reth, T Hofer and HR Rodewald. (2015). Fundamental properties of unperturbed haematopoiesis from stem cells in vivo. Nature 518: 542-546.

14. Ghimire S, D Weber, E Mavin, XN Wang, AM Dickinson and E Holler. (2017). Pathophysiology of GvHD and Other HSCT-Related Major Complications. Front Immunol 8: 79.

15. Cattina F, S Bernardi, V Mantovani, E Toffoletti, A Santoro, D Pastore, B Martino, G Console, G Martinelli and M Malagola. (2017). Single step multiple genotyping by MALDI-TOF mass spectrometry, for evaluation of minor histocompatibility antigens in patients submitted to allogeneic stem cell transplantation from HLA-matched related and unrelated donor. Hematol Rep 9: 7051.

16. Chen JY, M Miyanishi, SK Wang, S Yamazaki, R Sinha, KS Kao, J Seita, D Sahoo, H Nakauchi and IL Weissman. (2016). Hoxb5 marks long-term haematopoietic stem cells and reveals a homogenous perivascular niche. Nature 530: 223-227.

17. Spangrude GJ, S Heimfeld and IL Weissman. (1988). Purification and characterization of mouse hematopoietic stem cells. Science 241: 58-62.

18. Sakaguchi H, H Muramatsu, D Hasegawa, K Kudo, H Ishida, N Yoshida, K Koh, M Noguchi, N Shiba, S Tokimasa, T Fukuda, H Goto, T Miyamura, Y Nakazawa, Y Hashii, M Inoue, Y Atsuta and Pediatric AML Working Group of the Japan Society for Hematopoietic Cell Transplantation. (2019). Comparison of conditioning regimens for autologous stem cell transplantation in children with acute myeloid leukemia: A nationwide retrospective study in Japan. Pediatr Blood Cancer 66: e27459.

19. Choe HK, U Gergis, SA Mayer, H Nagar, AA Phillips, TB Shore, MJ Smith and K van Besien. (2017). The Addition of Low-Dose Total Body Irradiation to Fludarabine and Melphalan Conditioning in Haplocord Transplantation for High-Risk Hematological Malignancies. Transplantation 101: e38.

20. Chhabra A, AM Ring, K Weiskopf, PJ Schnorr, S Gordon, AC Le, HS Kwon, NG Ring, J Volkmer, PY Ho, S Tseng, IL Weissman and JA Shizuru. (2016). Hematopoietic stem cell transplantation in immunocompetent hosts without radiation or chemotherapy. Sci Transl Med 8: 351ra105.

21. Weycker D AUID- ORCID: http://orcid.org/0000-0002-5405-2215, R Doroff, A Hanau, C Bowers, R Belani, D Chandler, A Lonshteyn, M Bensink and GH Lyman. Use and effectiveness of pegfilgrastim prophylaxis in US clinical practice:a retrospective observational study. 
22. Waldhuter N, W Kohler, PG Hemmati, C Jehn, R Peceny, GL Vuong, R Arnold and JS Kuhl. (2019). Allogeneic hematopoietic stem cell transplantation with myeloablative conditioning for adult cerebral Xlinked adrenoleukodystrophy. J Inherit Metab Dis 42: 313-324.

23. Ho VT, HT Kim, D Liney, E Milford, J Gribben, C Cutler, SJ Lee, JH Antin, RJ Soiffer and EP Alyea. (2006). HLA-C mismatch is associated with inferior survival after unrelated donor non-myeloablative hematopoietic stem cell transplantation. Bone Marrow Transplant 37: 845-850.

24. Madden LM, RJ Hayashi, KW Chan, MA Pulsipher, D Douglas, GA Hale, S Chaudhury, P Haut, KA Kasow, AL Gilman, LM Murray and S Shenoy. (2016). Long-Term Follow-Up after Reduced-Intensity Conditioning and Stem Cell Transplantation for Childhood Nonmalignant Disorders. Biol Blood Marrow Transplant 22: 1467-1472.

25. Cabrero M, A Martin, J Briones, J Gayoso, I Jarque, J Lopez, C Grande, I Heras, R Arranz, T Bernal, E Perez-Lopez, O Lopez-Godino, E Conde and D Caballero. (2017). Phase II Study of Yttrium-90Ibritumomab Tiuxetan as Part of Reduced-Intensity Conditioning (with Melphalan, Fludarabine +/Thiotepa) for Allogeneic Transplantation in Relapsed or Refractory Aggressive B Cell Lymphoma: A GELTAMO Trial. Biol Blood Marrow Transplant 23: 53-59.

26. Epperla N, KW Ahn, S Ahmed, M Jagasia, A DiGilio, SM Devine, S Jaglowski, V Kennedy, AR Rezvani, SM Smith, A Sureda, TS Fenske, MA Kharfan-Dabaja, P Armand and M Hamadani. (2017). Rituximabcontaining reduced-intensity conditioning improves progression-free survival following allogeneic transplantation in B cell non-Hodgkin lymphoma. J Hematol Oncol 10: 117-017-0487-y.

27. Wright DE, AJ Wagers, AP Gulati, FL Johnson and IL Weissman. (2001). Physiological migration of hematopoietic stem and progenitor cells. Science 294: 1933-1936.

28. Voog J and DL Jones. (2010). Stem cells and the niche: a dynamic duo. Cell Stem Cell 6: 103-115.

29. Wilson A, GM Oser, M Jaworski, WE Blanco-Bose, E Laurenti, C Adolphe, MA Essers, HR Macdonald and A Trumpp. (2007). Dormant and self-renewing hematopoietic stem cells and their niches. Ann N Y Acad Sci 1106: 64-75.

30. Crane GM, E Jeffery and SJ Morrison. (2017). Adult haematopoietic stem cell niches. Nat Rev Immunol 17: 573-590.

31. Morrison SJ and DT Scadden. (2014). The bone marrow niche for haematopoietic stem cells. Nature 505: 327-334.

32. Schofield R. (1978). The relationship between the spleen colony-forming cell and the haemopoietic stem cell. Blood Cells 4: 7-25.

33. Friedenstein AJ, RK Chailakhyan, NV Latsinik, AF Panasyuk and IV Keiliss-Borok. (1974). Stromal cells responsible for transferring the microenvironment of the hemopoietic tissues. Cloning in vitro and retransplantation in vivo. Transplantation 17: 331-340. 
34. Cras A, D Farge, T Carmoi, JJ Lataillade, DD Wang and L Sun. (2015). Update on mesenchymal stem cell-based therapy in lupus and scleroderma. Arthritis Res Ther 17: 301-015-0819-7.

35. Gharravi AM, A Jafar, M Ebrahimi, A Mahmodi, E Pourhashemi, N Haseli, N Talaie and P Hajiasgarli. (2018). Current status of stem cell therapy, scaffolds for the treatment of diabetes mellitus 12: 11331139.

36. Maria AT, M Maumus, A Le Quellec, C Jorgensen, D Noel and P Guilpain. (2017). Adipose-Derived Mesenchymal Stem Cells in Autoimmune Disorders: State of the Art and Perspectives for Systemic Sclerosis. Clin Rev Allergy Immunol 52: 234-259.

37. Yu VW and DT Scadden. (2016). Hematopoietic Stem Cell and Its Bone Marrow Niche. Curr Top Dev Biol 118: 21-44.

38. Khlusov IA, LS Litvinova, MY Khlusova and KA Yurova. (2018). Concept of Hematopoietic and Stromal Niches for Cell-Based Diagnostics and Regenerative Medicine (a Review). Curr Pharm Des 24: 3034-3054.

39. Mendez-Ferrer S, TV Michurina, F Ferraro, AR Mazloom, BD Macarthur, SA Lira, DT Scadden, A Ma'ayan, GN Enikolopov and PS Frenette. (2010). Mesenchymal and haematopoietic stem cells form a unique bone marrow niche. Nature 466: 829-834.

40. Zhou BO, R Yue, MM Murphy, JG Peyer and SJ Morrison. (2014). Leptin-receptor-expressing mesenchymal stromal cells represent the main source of bone formed by adult bone marrow. Cell Stem Cell 15: 154-168.

41. Askmyr M, NA Sims, TJ Martin and LE Purton. (2009). What is the true nature of the osteoblastic hematopoietic stem cell niche?. Trends Endocrinol Metab 20: 303-309.

42. Askenasy N, T Zorina, DL Farkas and I Shalit. (2002). Transplanted hematopoietic cells seed in clusters in recipient bone marrow in vivo. Stem Cells 20: 301-310.

43. Haylock DN, B Williams, HM Johnston, MC Liu, KE Rutherford, GA Whitty, PJ Simmons, I Bertoncello and SK Nilsson. (2007). Hemopoietic stem cells with higher hemopoietic potential reside at the bone marrow endosteum. Stem Cells 25: 1062-1069.

44. Purton LE and DT Scadden. (2008). The hematopoietic stem cell niche. In: StemBook Louise E. Purton and David T. Scadden, Cambridge (MA),

45. Stier S, Y Ko, R Forkert, C Lutz, T Neuhaus, E Grunewald, T Cheng, D Dombkowski, LM Calvi, SR Rittling and DT Scadden. (2005). Osteopontin is a hematopoietic stem cell niche component that negatively regulates stem cell pool size. J Exp Med 201: 1781-1791.

46. Ding L and SJ Morrison. (2013). Haematopoietic stem cells and early lymphoid progenitors occupy distinct bone marrow niches. Nature 495: 231-235.

47. Ferraro F, S Lymperi, S Mendez-Ferrer, B Saez, JA Spencer, BY Yeap, E Masselli, G Graiani, L Prezioso, EL Rizzini, M Mangoni, V Rizzoli, SM Sykes, CP Lin, PS Frenette, F Quaini and DT Scadden. (2011). 
Diabetes impairs hematopoietic stem cell mobilization by altering niche function. Sci Transl Med 3: 104 ra101.

48. Martin TJ and NA Sims. (2005). Osteoclast-derived activity in the coupling of bone formation to resorption. Trends Mol Med 11: 76-81.

49. Hogan CJ, EJ Shpall and G Keller. (2002). Differential long-term and multilineage engraftment potential from subfractions of human CD34+ cord blood cells transplanted into NOD/SCID mice. Proc Natl Acad Sci U S A 99: 413-418.

50. Omatsu Y, T Sugiyama, H Kohara, G Kondoh, N Fujii, K Kohno and T Nagasawa. (2010). The essential functions of adipo-osteogenic progenitors as the hematopoietic stem and progenitor cell niche. Immunity 33: 387-399.

51. Tzeng YS, H Li, YL Kang, WC Chen, WC Cheng and DM Lai. (2011). Loss of Cxcl12/Sdf-1 in adult mice decreases the quiescent state of hematopoietic stem/progenitor cells and alters the pattern of hematopoietic regeneration after myelosuppression. Blood 117: 429-439.

52. Greenbaum A, YM Hsu, RB Day, LG Schuettpelz, MJ Christopher, JN Borgerding, T Nagasawa and DC Link. (2013). CXCL12 in early mesenchymal progenitors is required for haematopoietic stem-cell maintenance. Nature 495: 227-230.

53. Kunisaki Y, I Bruns, C Scheiermann, J Ahmed, S Pinho, D Zhang, T Mizoguchi, Q Wei, D Lucas, K Ito, JC Mar, A Bergman and PS Frenette. (2013). Arteriolar niches maintain haematopoietic stem cell quiescence. Nature 502: 637-643.

54. Bradfute SB, TA Graubert and MA Goodell. (2005). Roles of Sca-1 in hematopoietic stem/progenitor cell function. Exp Hematol 33: 836-843.

55. Sugiyama T, Y Omatsu and T Nagasawa. (2018). Niches for hematopoietic stem cells and immune cell progenitors. Int Immunol.

56. Ding L, TL Saunders, G Enikolopov and SJ Morrison. (2012). Endothelial and perivascular cells maintain haematopoietic stem cells. Nature 481: 457-462.

57. Zhang Z, P Zhu, Y Zhou, Y Sheng, Y Hong, D Xiang, Z Qian, J Mosenson and WS Wu. (2017). A novel slug-containing negative-feedback loop regulates SCF/c-Kit-mediated hematopoietic stem cell selfrenewal. Leukemia 31: 403-413.

58. Driessen RL, HM Johnston and SK Nilsson. (2003). Membrane-bound stem cell factor is a key regulator in the initial lodgment of stem cells within the endosteal marrow region. Exp Hematol 31: 1284-1291.

59. Lacombe J, G Krosl, M Tremblay, B Gerby, R Martin, PD Aplan, S Lemieux and T Hoang. (2013). Genetic interaction between Kit and Scl. Blood 122: 1150-1161. 
60. Balduino A, V Mello-Coelho, Z Wang, RS Taichman, PH Krebsbach, AT Weeraratna, KG Becker, W de Mello, DD Taub and R Borojevic. (2012). Molecular signature and in vivo behavior of bone marrow endosteal and subendosteal stromal cell populations and their relevance to hematopoiesis. Exp Cell Res 318: 2427-2437.

61. Mendez-Ferrer S, D Lucas, M Battista and PS Frenette. (2008). Haematopoietic stem cell release is regulated by circadian oscillations. Nature 452: 442-447.

62. Seita J and IL Weissman. (2010). Hematopoietic stem cell: self-renewal versus differentiation. Wiley Interdiscip Rev Syst Biol Med 2: 640-653.

63. Rodriguez-Fraticelli AE, SL Wolock, CS Weinreb, R Panero, SH Patel, M Jankovic, J Sun, RA Calogero, AM Klein and FD Camargo. (2018). Clonal analysis of lineage fate in native haematopoiesis. Nature 553: 212-216.

64. Kondo M, DC Scherer, T Miyamoto, AG King, K Akashi, K Sugamura and IL Weissman. (2000). Cell-fate conversion of lymphoid-committed progenitors by instructive actions of cytokines. Nature 407: 383-386.

65. Lu R, A Czechowicz, J Seita, D Jiang and IL Weissman. (2019). Clonal-level lineage commitment pathways of hematopoietic stem cells in vivo. Proc Natl Acad Sci U S A 116: 1447-1456.

66. Pietras EM, D Reynaud, YA Kang, D Carlin, FJ Calero-Nieto, AD Leavitt, JM Stuart, B Gottgens and E Passegue. (2015). Functionally Distinct Subsets of Lineage-Biased Multipotent Progenitors Control Blood Production in Normal and Regenerative Conditions. Cell Stem Cell 17: 35-46.

67. Klamer SE, YL Dorland, M Kleijer, D Geerts, WE Lento, CE van der Schoot, M von Lindern and C Voermans. (2018). TGFBI Expressed by Bone Marrow Niche Cells and Hematopoietic Stem and Progenitor Cells Regulates Hematopoiesis. Stem Cells Dev 27: 1494-1506.

68. Greenberger JS and M Epperly. (2009). Bone marrow-derived stem cells and radiation response. Semin Radiat Oncol 19: 133-139.

69. Nilsson SK, HM Johnston, GA Whitty, B Williams, RJ Webb, DT Denhardt, I Bertoncello, LJ Bendall, PJ Simmons and DN Haylock. (2005). Osteopontin, a key component of the hematopoietic stem cell niche and regulator of primitive hematopoietic progenitor cells. Blood 106: 1232-1239.

70. Le ON, F Rodier, F Fontaine, JP Coppe, J Campisi, J DeGregori, C Laverdiere, V Kokta, E Haddad and CM Beausejour. (2010). lonizing radiation-induced long-term expression of senescence markers in mice is independent of p53 and immune status. Aging Cell 9: 398-409.

71. Carbonneau CL, G Despars, S Rojas-Sutterlin, A Fortin, O Le, T Hoang and CM Beausejour. (2012). lonizing radiation-induced expression of INK4a/ARF in murine bone marrow-derived stromal cell populations interferes with bone marrow homeostasis. Blood 119: 717-726.

72. Alessio N, S Del Gaudio, S Capasso, G Di Bernardo, S Cappabianca, M Cipollaro, G Peluso and U Galderisi. (2015). Low dose radiation induced senescence of human mesenchymal stromal cells and impaired the autophagy process. Oncotarget 6: 8155-8166. 
73. Cameron BD, KR Sekhar, M Ofori and ML Freeman. (2018). The Role of Nrf2 in the Response to Normal Tissue Radiation Injury. Radiat Res 190: 99-106.

74. Kink JA, MH Forsberg, S Reshetylo, S Besharat, CJ Childs, JD Pederson, A Gendron-Fitzpatrick, M Graham, PD Bates, EG Schmuck, A Raval, P Hematti and CM Capitini. (2019). Macrophages Educated with Exosomes from Primed Mesenchymal Stem Cells Treat Acute Radiation Syndrome by Promoting Hematopoietic Recovery. Biol Blood Marrow Transplant 25: 2124-2133.

75. Kiang JG. (2016). Adult Mesenchymal Stem Cells and Radiation Injury. Health Phys 111: 198-203.

76. Martin LM, B Marples, AM Davies, A Atzberger, C Edwards, TH Lynch, D Hollywood and L Marignol. (2013). DNA mismatch repair protein MSH2 dictates cellular survival in response to low dose radiation in endometrial carcinoma cells. Cancer Lett 335: 19-25.

77. Martin LM, B Marples, TH Lynch, D Hollywood and L Marignol. (2013). Exposure to low dose ionising radiation: molecular and clinical consequences. Cancer Lett 338: 209-218.

78. DiCarlo AL, R Tamarat, Cl Rios, M Benderitter, CW Czarniecki, TC Allio, F Macchiarini, BW Maidment and JR Jourdain. (2017). Cellular Therapies for Treatment of Radiation Injury: Report from a NIH/NIAID and IRSN Workshop. Radiat Res 188: e54-e75.

79. Bolus NE. (2017). Basic Review of Radiation Biology and Terminology. J Nucl Med Technol 45: 259264.

80. Shao L, Y Sun, Z Zhang, W Feng, Y Gao, Z Cai, ZZ Wang, AT Look and WS Wu. (2010). Deletion of proapoptotic Puma selectively protects hematopoietic stem and progenitor cells against high-dose radiation. Blood 115: 4707-4714.

81. Wang J, Q Sun, Y Morita, H Jiang, A Gross, A Lechel, K Hildner, LM Guachalla, A Gompf, D Hartmann, A Schambach, T Wuestefeld, D Dauch, H Schrezenmeier, WK Hofmann, H Nakauchi, Z Ju, HA Kestler, L Zender and KL Rudolph. (2012). A differentiation checkpoint limits hematopoietic stem cell self-renewal in response to DNA damage. Cell 148: 1001-1014.

82. Wang Y, L Liu, SK Pazhanisamy, H Li, A Meng and D Zhou. (2010). Total body irradiation causes residual bone marrow injury by induction of persistent oxidative stress in murine hematopoietic stem cells. Free Radic Biol Med 48: 348-356.

83. Singh S, FR Kloss, R Brunauer, M Schimke, A Jamnig, B Greiderer-Kleinlercher, G Klima, J Rentenberger, T Auberger, O Hachl, M Rasse, R Gassner and G Lepperdinger. (2012). Mesenchymal stem cells show radioresistance in vivo. J Cell Mol Med 16: 877-887.

84. Sugrue T, JA Brown, NF Lowndes and R Ceredig. (2013). Multiple facets of the DNA damage response contribute to the radioresistance of mouse mesenchymal stromal cell lines. Stem Cells 31: 137-145.

85. Cuende N, JEJ Rasko, MBC Koh, M Dominici and L Ikonomou. (2018). Cell, tissue and gene products with marketing authorization in 2018 worldwide. Cytotherapy 20: 1401-1413. 
86. Galipeau J, M Krampera, J Barrett, F Dazzi, RJ Deans, J DeBruijn, M Dominici, WE Fibbe, AP Gee, JM Gimble, P Hematti, MB Koh, K LeBlanc, I Martin, IK McNiece, M Mendicino, S Oh, L Ortiz, DG Phinney, V Planat, Y Shi, DF Stroncek, S Viswanathan, DJ Weiss and L Sensebe. (2016). International Society for Cellular Therapy perspective on immune functional assays for mesenchymal stromal cells as potency release criterion for advanced phase clinical trials. Cytotherapy 18: 151-159.

87. Drouet M, F Mourcin, N Grenier, C Delaunay, JF Mayol, JJ Lataillade, A Peinnequin and F Herodin. (2005). Mesenchymal stem cells rescue CD34+ cells from radiation-induced apoptosis and sustain hematopoietic reconstitution after coculture and cografting in lethally irradiated baboons: is autologous stem cell therapy in nuclear accident settings hype or reality?. Bone Marrow Transplant 35: 1201-1209.

88. Shim S, SB Lee, JG Lee, WS Jang, SJ Lee, S Park and SS Lee. (2013). Mitigating effects of hUCB-MSCS on the hematopoietic syndrome resulting from total body irradiation. Exp Hematol 41: 346-53.e2.

89. Kurtzberg J, H Abdel-Azim, P Carpenter, S Chaudhury, B Horn, K Mahadeo, E Nemecek, S Neudorf, V Prasad, S Prockop, T Quigg, P Satwani, A Cheng, E Burke, J Hayes, D Skerrett and MSB-GVHD001/002 Study Group. (2020). A Phase 3, Single-Arm, Prospective Study of Remestemcel-L, Ex Vivo CultureExpanded Adult Human Mesenchymal Stromal Cells for the Treatment of Pediatric Patients Who Failed to Respond to Steroid Treatment for Acute Graft-versus-Host Disease. Biol Blood Marrow Transplant 26: 845-854.

90. Kurtzberg J, S Prockop, S Chaudhury, B Horn, E Nemecek, V Prasad, P Satwani, P Teira, J Hayes, E Burke and MSB-275 Study Group. (2020). Study 275: Updated Expanded Access Program for Remestemcel-L in Steroid-Refractory Acute Graft-versus-Host Disease in Children. Biol Blood Marrow Transplant 26: 855-864.

91. Sher N and R Ofir. (2018). Placenta-Derived Adherent Stromal Cell Therapy for Hematopoietic Disorders: A Case Study of PLX-R18. Cell Transplant 27: 140-150.

92. Papait A, E Vertua, M Magatti, S Ceccariglia, S De Munari, AR Silini, M Sheleg, R Ofir and O Parolini. (2020). Mesenchymal Stromal Cells from Fetal and Maternal Placenta Possess Key Similarities and Differences: Potential Implications for Their Applications in Regenerative Medicine. Cells 9: 10.3390/cells9010127.

93. Chinnadurai R, MH Forsberg, JA Kink, P Hematti and CM Capitini. (2020). Use of MSCs and MSCeducated macrophages to mitigate hematopoietic acute radiation syndrome. Curr Stem Cell Rep 6: 7785.

94. Galotto M, G Berisso, L Delfino, M Podesta, L Ottaggio, S Dallorso, C Dufour, GB Ferrara, A Abbondandolo, G Dini, A Bacigalupo, R Cancedda and R Quarto. (1999). Stromal damage as consequence of high-dose chemo/radiotherapy in bone marrow transplant recipients. Exp Hematol 27: 1460-1466.

95. Kemp K, R Morse, S Wexler, C Cox, E Mallam, J Hows and C Donaldson. (2010). Chemotherapyinduced mesenchymal stem cell damage in patients with hematological malignancy. Ann Hematol 89: 701-713. 
96. Kemp K, R Morse, K Sanders, J Hows and C Donaldson. (2011). Alkylating chemotherapeutic agents cyclophosphamide and melphalan cause functional injury to human bone marrow-derived mesenchymal stem cells. Ann Hematol 90: 777-789.

97. Tang C, MH Li, YL Chen, HY Sun, SL Liu, WW Zheng, MY Zhang, H Li, W Fu, WJ Zhang, AB Liang, ZH Tang, DL Hong, BS Zhou and CW Duan. (2018). Chemotherapy-induced niche perturbs hematopoietic reconstitution in B-cell acute lymphoblastic leukemia. J Exp Clin Cancer Res 37: 204-018-0859-3.

98. Somaiah C, A Kumar, R Sharma, A Sharma, T Anand, J Bhattacharyya, D Das, S Deka Talukdar and BG Jaganathan. (2018). Mesenchymal stem cells show functional defect and decreased anti-cancer effect after exposure to chemotherapeutic drugs. J Biomed Sci 25: 5-018-0407-7.

99. Lopez Perez R, F Munz, D Vidoni, A Ruhle, T Trinh, S Sisombath, B Zou, P Wuchter, J Debus, AL Grosu, R Saffrich, PE Huber and NH Nicolay. (2019). Mesenchymal stem cells preserve their stem cell traits after exposure to antimetabolite chemotherapy. Stem Cell Res 40: 101536.

100. Yuan YH, SS Zhao, XL Wang, ZP Teng, DS Li and Y Zeng. (2017). HIV-1 p55-gag protein induces senescence of human bone marrow mesenchymal stem cells and reduces their capacity to support expansion of hematopoietic stem cells in vitro. Cell Biol Int 41: 969-981.

101. Geyh S, S Oz, RP Cadeddu, J Frobel, B Bruckner, A Kundgen, R Fenk, I Bruns, C Zilkens, D Hermsen, N Gattermann, G Kobbe, U Germing, F Lyko, R Haas and T Schroeder. (2013). Insufficient stromal support in MDS results from molecular and functional deficits of mesenchymal stromal cells. Leukemia 27: 18411851.

102. Andre T, N Meuleman, B Stamatopoulos, C De Bruyn, K Pieters, D Bron and L Lagneaux. (2013). Evidences of early senescence in multiple myeloma bone marrow mesenchymal stromal cells. PLoS One 8: e59756.

103. Mehta RS, RM Saliba, K Cao, I Kaur, K Rezvani, J Chen, A Olson, S Parmar, N Shah, D Marin, A Alousi, C Hosing, U Popat, P Kebriaei, R Champlin, M de Lima, D Skerrett, E Burke, EJ Shpall and B Oran. (2017). Ex Vivo Mesenchymal Precursor Cell-Expanded Cord Blood Transplantation after Reduced-Intensity Conditioning Regimens Improves Time to Neutrophil Recovery. Biol Blood Marrow Transplant 23: 13591366.

104. Buckley SA, M Othus, V Vainstein, JL Abkowitz, EH Estey and RB Walter. (2014). Prediction of adverse events during intensive induction chemotherapy for acute myeloid leukemia or high-grade myelodysplastic syndromes. Am J Hematol 89: 423-428.

105. Abbuehl JP, Z Tatarova, W Held and J Huelsken. (2017). Long-Term Engraftment of Primary Bone Marrow Stromal Cells Repairs Niche Damage and Improves Hematopoietic Stem Cell Transplantation. Cell Stem Cell 21: 241-255.e6.

106. Nilsson SK, MS Dooner, HU Weier, B Frenkel, JB Lian, GS Stein and PJ Quesenberry. (1999). Cells capable of bone production engraft from whole bone marrow transplants in nonablated mice. J Exp Med 189: 729-734. 
107. Migliaccio AR. (2016). To condition or not to condition-That is the question: The evolution of nonmyeloablative conditions for transplantation. Exp Hematol 44: 706-712.

108. Brecher G, JD Ansell, HS Micklem, JH Tjio and EP Cronkite. (1982). Special proliferative sites are not needed for seeding and proliferation of transfused bone marrow cells in normal syngeneic mice. Proc Natl Acad Sci U S A 79: 5085-5087.

109. Bhattacharya D, A Czechowicz, AG Ooi, DJ Rossi, D Bryder and IL Weissman. (2009). Niche recycling through division-independent egress of hematopoietic stem cells. J Exp Med 206: 2837-2850.

110. Taya Y, Y Ota, AC Wilkinson, A Kanazawa, H Watarai, M Kasai, H Nakauchi and S Yamazaki. (2016). Depleting dietary valine permits nonmyeloablative mouse hematopoietic stem cell transplantation. Science 354: 1152-1155.

111. Cronkite EP, JE Bullis and G Brecher. (1985). Marrow transfusions increase pluripotential stem cells in normal hosts. Exp Hematol 13: 802.

112. Nguyen L, Z Wang, AY Chowdhury, E Chu, J Eerdeng, D Jiang and R Lu. (2018). Functional compensation between hematopoietic stem cell clones in vivo. EMBO Rep 19:

10.15252/embr.201745702. Epub 2018 May 30.

113. Shimoto M, T Sugiyama and T Nagasawa. (2017). Numerous niches for hematopoietic stem cells remain empty during homeostasis. Blood 129: 2124-2131.

114. Purton LE and DT Scadden. (2007). Limiting factors in murine hematopoietic stem cell assays. Cell Stem Cell 1: 263-270.

115. Harrison DE, CT Jordan, RK Zhong and CM Astle. (1993). Primitive hemopoietic stem cells: direct assay of most productive populations by competitive repopulation with simple binomial, correlation and covariance calculations. Exp Hematol 21: 206-219.

116. Acar M, KS Kocherlakota, MM Murphy, JG Peyer, H Oguro, CN Inra, C Jaiyeola, Z Zhao, K LubyPhelps and SJ Morrison. (2015). Deep imaging of bone marrow shows non-dividing stem cells are mainly perisinusoidal. Nature 526: 126-130.

117. Kfoury Y and DT Scadden. (2015). Mesenchymal cell contributions to the stem cell niche. Cell Stem Cell 16: 239-253.

118. Rana T, MA Schultz, ML Freeman and S Biswas. (2012). Loss of Nrf2 accelerates ionizing radiationinduced bone loss by upregulating RANKL. Free Radic Biol Med 53: 2298-2307.

119. Chertkov JL, OA Gurevitch and GA Udalov. (1980). Role of bone marrow stroma in hemopoietic stem cell regulation. Exp Hematol 8: 770-778.

120. Najar M, H Fayyad-Kazan, WH Faour, M Merimi, EM Sokal, CA Lombard and H Fahmi. (2019). Immunological modulation following bone marrow-derived mesenchymal stromal cells and Th17 lymphocyte co-cultures. Inflamm Res 68: 203-213. 
121. Varas F, T Grande, A Ramirez and JA Bueren. (2000). Implantation of bone marrow beneath the kidney capsule results in transfer not only of functional stroma but also of hematopoietic repopulating cells. Blood 96: 2307-2309.

122. Brewer C, E Chu, M Chin and R Lu. (2016). Transplantation Dose Alters the Differentiation Program of Hematopoietic Stem Cells. Cell Rep 15: 1848-1857.

123. Dexter TM. (1982). Is the marrow stroma transplantable?. Nature 298: 222-223.

124. Dominici M, K Le Blanc, I Mueller, I Slaper-Cortenbach, F Marini, D Krause, R Deans, A Keating, D Prockop and E Horwitz. (2006). Minimal criteria for defining multipotent mesenchymal stromal cells. The International Society for Cellular Therapy position statement. Cytotherapy 8: 315-317.

125. Balan A, G Lucchini, S Schmidt, A Schneider, L Tramsen, S Kuci, R Meisel, P Bader and T Lehrnbecher. (2014). Mesenchymal stromal cells in the antimicrobial host response of hematopoietic stem cell recipients with graft-versus-host disease--friends or foes?. Leukemia 28: 1941-1948.

126. Huaman O, J Bahamonde, B Cahuascanco, M Jervis, J Palomino, CG Torres and OA Peralta. (2019). Immunomodulatory and immunogenic properties of mesenchymal stem cells derived from bovine fetal bone marrow and adipose tissue. Res Vet Sci 124: 212-222.

127. Le Blanc K, C Tammik, K Rosendahl, E Zetterberg and O Ringden. (2003). HLA expression and immunologic properties of differentiated and undifferentiated mesenchymal stem cells. Exp Hematol 31: 890-896.

128. Javazon EH, KJ Beggs and AW Flake. (2004). Mesenchymal stem cells: paradoxes of passaging. Exp Hematol 32: 414-425.

129. Ryan JM, FP Barry, JM Murphy and BP Mahon. (2005). Mesenchymal stem cells avoid allogeneic rejection. J Inflamm (Lond) 2: 8-9255-2-8.

130. Klyushnenkova E, JD Mosca, V Zernetkina, MK Majumdar, KJ Beggs, DW Simonetti, RJ Deans and KR McIntosh. (2005). T cell responses to allogeneic human mesenchymal stem cells: immunogenicity, tolerance, and suppression. J Biomed Sci 12: 47-57.

131. Almeida-Porada G, CD Porada, N Tran and ED Zanjani. (2000). Cotransplantation of human stromal cell progenitors into preimmune fetal sheep results in early appearance of human donor cells in circulation and boosts cell levels in bone marrow at later time points after transplantation. Blood 95: 3620-3627.

132. Noort WA, AB Kruisselbrink, PS in't Anker, M Kruger, RL van Bezooijen, RA de Paus, MH Heemskerk, CW Lowik, JH Falkenburg, R Willemze and WE Fibbe. (2002). Mesenchymal stem cells promote engraftment of human umbilical cord blood-derived CD34(+) cells in NOD/SCID mice. Exp Hematol 30: 870-878. 
133. Maitra B, E Szekely, K Gjini, MJ Laughlin, J Dennis, SE Haynesworth and ON Koc. (2004). Human mesenchymal stem cells support unrelated donor hematopoietic stem cells and suppress T-cell activation. Bone Marrow Transplant 33: 597-604.

134. Hillmann A, AB Ahrberg, W Brehm, S Heller, C Josten, F Paebst and J Burk. (2016). Comparative Characterization of Human and Equine Mesenchymal Stromal Cells: A Basis for Translational Studies in the Equine Model. Cell Transplant 25: 109-124.

135. Ivanovska A, S Grolli, P Borghetti, F Ravanetti, V Conti, E De Angelis, F Macchi, R Ramoni, P Martelli, F Gazza and A Cacchioli. (2017). Immunophenotypical characterization of canine mesenchymal stem cells from perivisceral and subcutaneous adipose tissue by a species-specific panel of antibodies. Res Vet Sci 114: 51-58.

136. Gonzalo-Daganzo R, C Regidor, T Martin-Donaire, MA Rico, G Bautista, I Krsnik, R Fores, E Ojeda, I Sanjuan, JA Garcia-Marco, B Navarro, S Gil, R Sanchez, N Panadero, Y Gutierrez, M Garcia-Berciano, N Perez, I Millan, R Cabrera and MN Fernandez. (2009). Results of a pilot study on the use of third-party donor mesenchymal stromal cells in cord blood transplantation in adults. Cytotherapy 11: 278-288.

137. Ball LM, ME Bernardo, H Roelofs, A Lankester, A Cometa, RM Egeler, F Locatelli and WE Fibbe. (2007). Cotransplantation of ex vivo expanded mesenchymal stem cells accelerates lymphocyte recovery and may reduce the risk of graft failure in haploidentical hematopoietic stem-cell transplantation. Blood 110: 2764-2767.

138. Chulpanova DS, KV Kitaeva, LG Tazetdinova, V James, AA Rizvanov and VV Solovyeva. (2018). Application of Mesenchymal Stem Cells for Therapeutic Agent Delivery in Anti-tumor Treatment. Front Pharmacol 9: 259.

139. Lalu MM, L McIntyre, C Pugliese, D Fergusson, BW Winston, JC Marshall, J Granton, DJ Stewart and Canadian Critical Care Trials Group. (2012). Safety of cell therapy with mesenchymal stromal cells (SafeCell): a systematic review and meta-analysis of clinical trials. PLoS One 7: e47559.

140. Kawabori M, H Shichinohe, S Kuroda and K Houkin. (2020). Clinical Trials of Stem Cell Therapy for Cerebral Ischemic Stroke. Int J Mol Sci 21: 10.3390/ijms21197380.

141. Al-Khawaga S and EM Abdelalim. (2020). Potential application of mesenchymal stem cells and their exosomes in lung injury: an emerging therapeutic option for COVID-19 patients. Stem Cell Res Ther 11: 437-020-01963-6.

142. Kabat M, I Bobkov, S Kumar and M Grumet. (2020). Trends in mesenchymal stem cell clinical trials 2004-2018: Is efficacy optimal in a narrow dose range?. Stem Cells Transl Med 9: 17-27.

143. Bernardo ME and WE Fibbe. (2012). Safety and efficacy of mesenchymal stromal cell therapy in autoimmune disorders. Ann N Y Acad Sci 1266: 107-117.

144. Le Blanc K, F Frassoni, L Ball, F Locatelli, H Roelofs, I Lewis, E Lanino, B Sundberg, ME Bernardo, M Remberger, G Dini, RM Egeler, A Bacigalupo, W Fibbe, O Ringden and Developmental Committee of the 
European Group for Blood and Marrow Transplantation. (2008). Mesenchymal stem cells for treatment of steroid-resistant, severe, acute graft-versus-host disease: a phase II study. Lancet 371: 1579-1586.

145. Barberini DJ, NP Freitas, MS Magnoni, L Maia, AJ Listoni, MC Heckler, MJ Sudano, MA Golim, F da Cruz Landim-Alvarenga and RM Amorim. (2014). Equine mesenchymal stem cells from bone marrow, adipose tissue and umbilical cord: immunophenotypic characterization and differentiation potential. Stem Cell Res Ther 5: 25.

146. Potian JA, H Aviv, NM Ponzio, JS Harrison and P Rameshwar. (2003). Veto-like activity of mesenchymal stem cells: functional discrimination between cellular responses to alloantigens and recall antigens. J Immunol 171: 3426-3434.

147. Bartholomew A, C Sturgeon, M Siatskas, K Ferrer, K Mclntosh, S Patil, W Hardy, S Devine, D Ucker, R Deans, A Moseley and R Hoffman. (2002). Mesenchymal stem cells suppress lymphocyte proliferation in vitro and prolong skin graft survival in vivo. Exp Hematol 30: 42-48.

148. Liu H, DM Kemeny, BC Heng, HW Ouyang, AJ Melendez and T Cao. (2006). The immunogenicity and immunomodulatory function of osteogenic cells differentiated from mesenchymal stem cells. J Immunol 176: 2864-2871.

149. Terraza-Aguirre C, M Campos-Mora, R Elizondo-Vega, RA Contreras-Lopez, P Luz-Crawford, C Jorgensen and F Djouad. (2020). Mechanisms behind the Immunoregulatory Dialogue between Mesenchymal Stem Cells and Th17 Cells. Cells 9: 10.3390/cells9071660.

150. Nilsson SK, MS Dooner, CY Tiarks, HU Weier and PJ Quesenberry. (1997). Potential and distribution of transplanted hematopoietic stem cells in a nonablated mouse model. Blood 89: 4013-4020.

151. Blazar BR, WJ Murphy and M Abedi. (2012). Advances in graft-versus-host disease biology and therapy. Nat Rev Immunol 12: 443-458.

152. Pasquini MC, Z Wang, MM Horowitz and RP Gale. (2010). 2010 report from the Center for International Blood and Marrow Transplant Research (CIBMTR): current uses and outcomes of hematopoietic cell transplants for blood and bone marrow disorders. Clin Transpl: 87-105.

153. Bhattacharya D, DJ Rossi, D Bryder and IL Weissman. (2006). Purified hematopoietic stem cell engraftment of rare niches corrects severe lymphoid deficiencies without host conditioning. J Exp Med 203: 73-85.

154. Kaufman CL, YL Colson, SM Wren, S Watkins, RL Simmons and ST Ildstad. (1994). Phenotypic characterization of a novel bone marrow-derived cell that facilitates engraftment of allogeneic bone marrow stem cells. Blood 84: 2436-2446.

155. Leventhal JR, MJ Elliott, ES Yolcu, LD Bozulic, DJ Tollerud, JM Mathew, I Konieczna, MG Ison, J Galvin, J Mehta, MD Badder, MM Abecassis, J Miller, L Gallon and ST Ildstad. (2015). Immune reconstitution/immunocompetence in recipients of kidney plus hematopoietic stem/facilitating cell transplants. Transplantation 99: 288-298. 
156. Omatsu Y, M Seike, T Sugiyama, T Kume and T Nagasawa. (2014). Foxc1 is a critical regulator of haematopoietic stem/progenitor cell niche formation. Nature 508: 536-540.

157. Itkin T, S Gur-Cohen, JA Spencer, A Schajnovitz, SK Ramasamy, AP Kusumbe, G Ledergor, Y Jung, I Milo, MG Poulos, A Kalinkovich, A Ludin, O Kollet, G Shakhar, JM Butler, S Rafii, RH Adams, DT Scadden, CP Lin and T Lapidot. (2016). Distinct bone marrow blood vessels differentially regulate haematopoiesis. Nature 532: 323-328.

158. Ludin A, T Itkin, S Gur-Cohen, A Mildner, E Shezen, K Golan, O Kollet, A Kalinkovich, Z Porat, G D'Uva, A Schajnovitz, E Voronov, DA Brenner, RN Apte, S Jung and T Lapidot. (2012). Monocytesmacrophages that express alpha-smooth muscle actin preserve primitive hematopoietic cells in the bone marrow. Nat Immunol 13: 1072-1082.

159. Ball LM, ME Bernardo, H Roelofs, MJ van Tol, B Contoli, JJ Zwaginga, MA Avanzini, A Conforti, A Bertaina, G Giorgiani, CM Jol-van der Zijde, M Zecca, K Le Blanc, F Frassoni, RM Egeler, WE Fibbe, AC Lankester and $\mathrm{F}$ Locatelli. (2013). Multiple infusions of mesenchymal stromal cells induce sustained remission in children with steroid-refractory, grade III-IV acute graft-versus-host disease. $\mathrm{Br} \mathrm{J}$ Haematol 163: 501-509.

160. Dander E, G Lucchini, P Vinci, M Introna, F Masciocchi, P Perseghin, A Balduzzi, S Bonanomi, D Longoni, G Gaipa, D Belotti, M Parma, A Algarotti, C Capelli, J Golay, A Rovelli, A Rambaldi, A Biondi, E Biagi and G D'Amico. (2012). Mesenchymal stromal cells for the treatment of graft-versus-host disease: understanding the in vivo biological effect through patient immune monitoring. Leukemia 26: 16811684.

161. Introna M, G Lucchini, E Dander, S Galimberti, A Rovelli, A Balduzzi, D Longoni, F Pavan, F Masciocchi, A Algarotti, C Mico, A Grassi, S Deola, I Cavattoni, G Gaipa, D Belotti, P Perseghin, M Parma, E Pogliani, J Golay, O Pedrini, C Capelli, S Cortelazzo, G D'Amico, A Biondi, A Rambaldi and E Biagi. (2014). Treatment of graft versus host disease with mesenchymal stromal cells: a phase I study on 40 adult and pediatric patients. Biol Blood Marrow Transplant 20: 375-381.

162. Ferrara JL, JE Levine, P Reddy and E Holler. (2009). Graft-versus-host disease. Lancet 373: 15501561.

163. Im KI, MJ Park, N Kim, JY Lim, HS Park, SH Lee, YS Nam, ES Lee, JH Lee, ML Cho and SG Cho. (2014). Induction of mixed chimerism using combinatory cell-based immune modulation with mesenchymal stem cells and regulatory T cells for solid-organ transplant tolerance. Stem Cells Dev 23: 2364-2376.

164. Sachs DH. (2018). Transplantation tolerance through mixed chimerism: From allo to xeno. Xenotransplantation 25: e12420.

165. Nti BK, JL Markman, S Bertera, AJ Styche, RJ Lakomy, VM Subbotin, M Trucco and TD Zorina. (2012). Treg cells in pancreatic lymph nodes: the possible role in diabetogenesis and $\beta$ cell regeneration in a T1D model 9: 455.

166. Jagasia MH, HT Greinix, M Arora, KM Williams, D Wolff, EW Cowen, J Palmer, D Weisdorf, NS Treister, GS Cheng, H Kerr, P Stratton, RF Duarte, GB McDonald, Y Inamoto, A Vigorito, S Arai, MB 
Datiles, D Jacobsohn, T Heller, CL Kitko, SA Mitchell, PJ Martin, H Shulman, RS Wu, CS Cutler, GB Vogelsang, SJ Lee, SZ Pavletic and ME Flowers. (2015). National Institutes of Health Consensus Development Project on Criteria for Clinical Trials in Chronic Graft-versus-Host Disease: I. The 2014 Diagnosis and Staging Working Group report. Biol Blood Marrow Transplant 21: 389-401.e1.

167. Le Blanc K, I Rasmusson, B Sundberg, C Gotherstrom, M Hassan, M Uzunel and O Ringden. (2004). Treatment of severe acute graft-versus-host disease with third party haploidentical mesenchymal stem cells. Lancet 363: 1439-1441.

168. Bonig H, Z Kuci, S Kuci, S Bakhtiar, O Basu, G Bug, M Dennis, J Greil, A Barta, KM Kallay, P Lang, G Lucchini, R Pol, A Schulz, KW Sykora, I Teichert von Luettichau, G Herter-Sprie, M Ashab Uddin, P Jenkin, A Alsultan, J Buechner, J Stein, A Kelemen, A Jarisch, J Soerensen, E Salzmann-Manrique, M Hutter, R Schafer, E Seifried, S Paneesha, I Novitzky-Basso, A Gefen, N Nevo, G Beutel, PG Schlegel, T Klingebiel and P Bader. (2019). Children and Adults with Refractory Acute Graft-versus-Host Disease Respond to Treatment with the Mesenchymal Stromal Cell Preparation "MSC-FFM"-Outcome Report of 92 Patients. Cells 8: $10.3390 /$ cells8121577.

169. Uccelli A and NK de Rosbo. (2015). The immunomodulatory function of mesenchymal stem cells: mode of action and pathways. Ann N Y Acad Sci 1351: 114-126.

170. Dander E, G Lucchini, P Vinci, M Introna, F Masciocchi, P Perseghin, A Balduzzi, S Bonanomi, D Longoni, G Gaipa, D Belotti, M Parma, A Algarotti, C Capelli, J Golay, A Rovelli, A Rambaldi, A Biondi, E Biagi and G D'Amico. (2012). Mesenchymal stromal cells for the treatment of graft-versus-host disease: understanding the in vivo biological effect through patient immune monitoring. Leukemia 26: 16811684.

171. Fujii S, Y Miura, A Fujishiro, T Shindo, Y Shimazu, H Hirai, H Tahara, A Takaori-Kondo, T Ichinohe and T Maekawa. (2018). Graft-Versus-Host Disease Amelioration by Human Bone Marrow Mesenchymal Stromal/Stem Cell-Derived Extracellular Vesicles Is Associated with Peripheral Preservation of Naive T Cell Populations. Stem Cells 36: 434-445.

172. Koc ON, SL Gerson, BW Cooper, SM Dyhouse, SE Haynesworth, AI Caplan and HM Lazarus. (2000). Rapid hematopoietic recovery after coinfusion of autologous-blood stem cells and culture-expanded marrow mesenchymal stem cells in advanced breast cancer patients receiving high-dose chemotherapy. J Clin Oncol 18: 307-316.

173. Le Blanc K, H Samuelsson, B Gustafsson, M Remberger, B Sundberg, J Arvidson, P Ljungman, H Lonnies, S Nava and O Ringden. (2007). Transplantation of mesenchymal stem cells to enhance engraftment of hematopoietic stem cells. Leukemia 21: 1733-1738.

174. Cheung TS, GM Bertolino, C Giacomini, M Bornhauser, F Dazzi and A Galleu. (2020). Mesenchymal Stromal Cells for Graft Versus Host Disease: Mechanism-Based Biomarkers. Front Immunol 11: 1338.

175. Alzahrani FA, IM Saadeldin, A Ahmad, D Kumar, El Azhar, AJ Siddiqui, B Kurdi, A Sajini, AF Alrefaei and S Jahan. (2020). The Potential Use of Mesenchymal Stem Cells and Their Derived Exosomes as Immunomodulatory Agents for COVID-19 Patients. Stem Cells Int 2020: 8835986. 
176. Fisher SA, A Cutler, C Doree, SJ Brunskill, SJ Stanworth, C Navarrete and J Girdlestone. (2019). Mesenchymal stromal cells as treatment or prophylaxis for acute or chronic graft-versus-host disease in haematopoietic stem cell transplant (HSCT) recipients with a haematological condition. Cochrane Database Syst Rev 1: CD009768.

177. Elgaz S, Z Kuci, S Kuci, H Bonig and P Bader. (2019). Clinical Use of Mesenchymal Stromal Cells in the Treatment of Acute Graft-versus-Host Disease. Transfus Med Hemother 46: 27-34. 